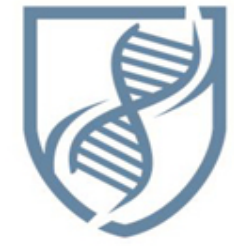

Journal of Bioscience and Applied Research
JBAAR

WWW.JBAAR ORG

\title{
Ultrastructure biomarker in Anisops sardeus (Heteroptera: Notonectidae) for the assessment and monitoring of Water Quality of Al-Mahmoudia Canal, Western Part of Nile Delta, Egypt
}

\author{
Dalia A. Kheirallah \\ Department of Zoology, Faculty of Science, Alexandria University, Alexandria 21511, Egypt. \\ Corresponding Author: Daliakheirallah@yahoo.com
}

\begin{abstract}
Ultrastructure biomarker reflects the effects of pollutants. The present study amid to evaluate the reproductive changes of the aquatic hemipteran insect Anisops sardeus (as a bioindicator organism), inhabiting three sites in AlMahmoudia canal (Abou-Hommous, Zarcon town, Manshia) which varied in physical and chemical properties. Mahmoudia canal is considered the main water source for Alexandria, which receive water from Rosetta branch at Mahmoudia city. The canal receives domestic and agriculture wastes from Zarcon Drain and other non-point sources. The present work is concerned with monitoring bioaccumulation of metal in the testes of $A$. sardeus using SEM-X-ray microanalysis and illustrating spermatogenesis disruptions. Insects caught from polluted sites (Zarcon town, Manshia) showed higher proportion of heavy metals in particular $\mathrm{Cu}, \mathrm{Zn}$ and $\mathrm{Hg}$ than in the less polluted site (Abou-Hommous). Many alterations of the general architecture of the testis were pronounced. Disruption and damage for the normal cellular organization were observed. In epithelial cells, aggregated clumps of heterochromatin, irregular nuclear envelope, cytoplasm with disorganized mitochondria and convolution of follicular wall were noticed. In spermatogonia the nucleus appeared with disintegrated nucleolus, vacuolated cytoplasm and degenerative changes in the mitochondria. According to the obtained results the water quality of Al-Mahmoudia canal was lower at the polluted sites and the watercourse from south to north direction has been increased in pollution sources. The results also showed that the intensity of the histopathological changes increased with increasing the
\end{abstract}

intensity of heavy metals. As a biomarker of exposure to toxicants, histopathology represents a useful tool to assess the degree of pollution.

Keywords: Al-Mahmoudia canal, aquatic insects, water assessment, biomarkers, X-ray microanalysis, testis.

\section{Introduction}

Biomarkers are useful tools to assess biological changes that may reveal exposure of organisms to environmental contaminants. Ultrastructure biomarker is capable of revealing sensitive and selectivity even at sublethal effects of pollutants (Sheriff 2007). Therefore, biomarkers can be used as both diagnostic and predictive tools of environmental exposure and adverse effects of toxic anthropogenic chemicals on aquatic organisms (Osman 2013). Heavy metals accumulated in the body of living organisms, and most ions are known to be toxic or carcinogenic (Fu and Wang, 2011). Unfortunately, due to the increasing use of these metals in industrial activities, human exposure to the heavy metals has been increasing in recent decades, causing serious harm to human health ( $\mathrm{Li}$ et al., 2001). Acute and chronic effects of heavy metals on various insects are frequently reported in the form of growth inhibition, developmental abnormalities, reduced reproduction, and decreased hatchability (Sildanchandra and Crane, 2000). Histopathological investigations on the reproductive system of insects affected by heavy metals provide an insight action of these toxic substances on the reproductive physiology of insects (Merin Emerald and Rameshkumar, 2012). Increasing the incidence of abnormality in male reproductive system may be a result of environmental pollution by man-made chemicals (Sharp 
and skakkeboek, 1993; Toppari et al., 1995). Such reproductive abnormalities not only injur the individual, but also threaten population (Colborn et al., 1993; Toppari et al., 1995). Zinc led to histopathological architecture of the testicular follicle, primary spermatocyte and secondary spermatocyte (Merin Emerald and Rameshkumar, 2012). Also Herranz et al. (2010) reported testicular damage mediated by cadmium. Heavy metals like copper are toxicants commonly found in mining, industrial, agricultural and waste effluents. In high concentrations this metal could have a negative effect not only on river systems, but also on marine populations and exposure to sublethal concentrations of copper induced histopathological changes in the testes which revealed disorganization of the lobules, disintegration of the spermatogonia as well as disintegration of the interstitial tissue (Pieterse, 2004). Xenobiotic metals like mercury often disrupt normal physiology of organisms (Sprague et al., 1971). Even at low concentration, mercury affects marine populations through impairment of physiological processes like reproduction (Crump and Trudeau, 2009). The reasons for using insect species as indicators because they give a rapid and sensitive response to accumulation of heavy metals (Cervera et al., 2004). It is known that the early stages of spermatogenesis are sensitive to any cellkilling effects (Creighton and Evans, 1941; Welshons and Russel, 1957; Suzuki and Egami, 1984; Hertel-Aas et al., 2007). The horizontal expansion in the Western Nile Delta Region depends on groundwater which is now being quickly depleted. To resolve this problem, the Government has been reviewing options to replace groundwater with surface water for irrigation system, (PPIAF, 2005).

For this reason, the present research was initiated with the objective of evaluating the surface water quality in one of the Western Delta Region, Al-Mahmoudia canal. Keeping in view environmental and health concerns due to increased heavy metal contamination, the present study was designed to investigate level of heavy metal contamination in AlMahmoudia canal by using insects as bioindicators and investigate the poisoning effects of this heavy metal on the mortality caused by ultrastructural damage.

\section{Materials and Methods Study site}

Al-Mahmoudia canal located at Northern West of Egypt (Fig. 1). A quantity of 3.360 billion m3/year have been discharged into Al-Mahmoudia canal from both Rosetta branch ( $\mathrm{km} \mathrm{1940)}$ via El-Atf pump stations at the head of the canal (The canal receives about $15 \mathrm{Mm3} /$ day water from Rosetta branch at Mahmoudia city) and AlKhandaq Eastern at km 13.200 on Al-Mahmoudia canal and the third water source is the drainage water from Zarkon drain at $\mathrm{km} 8.500$ on Al-Mahmoudia canal via Edko irrigation pump station which lifts part of Zarkon drain into the canal. Drinking water in Alexandria is supplied from surface water sources of Mahmoudia canal. Three sampling sites were chosen, less polluted site, AbouHommous (LP), medium polluted site, Zarcon town (MP) and highly polluted site, Manshia (HP) (Abdullah and Hussona, 2014).

\section{Sampling procedures:}

The Hemipteran insect Anisops sardeus sardeus Herrich-Schaeffer, 1849 (Heteroptera: Notonectidae) were identified according to Berchi (2011) and by using the lowest possible taxonomic level morphological keys (Tempelman \& von Haaren 2009). They were confined to the littoral zone in the canal (Brooks 1951; Barry 1997). High abundance of this bug was observed in habitats containing mosquitoes especially those rich at edges with Bermuda grass, that serve as shelter and resting sites for bugs. Sampling was accordingly restricted to such places.

The insect was sampled in the breeding period (AprilNovember).Three samples were collected in this period of the year 2013/2014. On each sampling occasion, a total approximate number of 20 males of uniform size $(1 \mathrm{~cm}$ males). This insect was collected in a metallic strainer (20 $\mathrm{cm}$ in diameter) with an aluminum handle before being transferred into glass containers filled with the canal water according to the specific sampling locations. Insects were then transported to the laboratory where sorting was carried out. Sorted insects were washed in running water to remove any debris.

\section{Bioaccumulation of metals}

Levels of accumulated elements in testes were detected in un-coated specimens using Jeol scanning electron microscope-5300 equipped with a Link-Isis energy dispersive X-ray microanalyzer. A stationary spot (X500) was analyzed at random for $110 \mathrm{sec}$. Due to heterogeneous distribution of trace metals, at least three points on each specimen were measured to check for internal variability of trace metal composition.

\section{Preparation of materials for electron microscopy}

Testes of fresh adult male insects collected from the inspected locations were removed and fixed by immersing them immediately in ${ }_{4} \mathrm{~F}_{1} \mathrm{G}$ in phosphate buffer solution ( $\mathrm{pH}$ 7.2) at $4^{\circ} \mathrm{C}$ for 3 hours. Specimens were then postfixed in $2 \% \mathrm{OsO}_{4}$ in the same buffer for 2 hours. Samples were washed in the buffer and dehydrated at $4^{\circ} \mathrm{C}$ through a graded series of ethanol. Specimens were embedded in Epon-araldite mixture in labelled beam capsules. Ultrathin sections (60-70 nm thick) were cut from testes of males collected from the selected locations for TEM. These ultrathin sections were of either pale gold or silver interference colour and were picked upon 200 mesh naked copper grids. Grids were double stained with uranyle for $1 / 2$ hr. and lead citrate for 20-30 min. (Reynolds, 1963). Scoping and photographing the grids was achieved by Joel 100CX TEM, at E.M. Unit, Faculty of Science, Alexandria University.

\section{Results}

\section{Metal accumulation patterns}

$\mathrm{X}$-ray spectra of testes revealed the presence of 13 elements including $\mathrm{Na}, \mathrm{Mg}, \mathrm{Al}, \mathrm{Si}, \mathrm{P}, \mathrm{S}, \mathrm{K}, \mathrm{Ca}, \mathrm{Fe}, \mathrm{Cu}, \mathrm{Zn}$, $\mathrm{Cd}$ and $\mathrm{Hg}$. $\mathrm{Cu}, \mathrm{Zn}, \mathrm{Hg}$ and $\mathrm{Al}$ were the toxic metals showing high levels and large variations among the different sites. Trends in proportions of $\mathrm{Na}, \mathrm{P}, \mathrm{S}, \mathrm{K}, \mathrm{Mg}$, Fe, Cd, Si and Ca were inconsistent. 
In samples collected from the less polluted location I (LP) during the studied period (breeding period from April to November), a representative $\mathrm{X}$-ray spectrum of testes showed smaller peaks of $\mathrm{Al}, \mathrm{Cu}$ and $\mathrm{Zn}$ (Fig.2). In location II (MP), Hg was detected in considerable proportion as well as $\mathrm{Al}, \mathrm{S}$, and $\mathrm{P}$. However, $\mathrm{Cu}, \mathrm{Zn}$ and $\mathrm{Cd}$ were present in small proportions (Fig.3). On the other hand, $\mathrm{Cu}$ and $\mathrm{Zn}$ attained their highest levels in testes of insects from location III (HP). Hg was detected in considerable proportion as well as $\mathrm{P}, \mathrm{Mg}, \mathrm{Al}$ and $\mathrm{S}$ (Fig.4).

\section{Electron microscopy}

In the electron micrographs the testis epithelial cells of insects from location I (LP) appeared with large ovoid flat nucleus with a fine light and non-condensed chromatin granulation. The nucleus are surrounded by clear nuclear envelope. The epithelial cells are characterized by a reduced cytoplasmic / nuclear ratio. The cytoplasm contained mitochondria with variable shapes and sizes. The epithelium advances towards the interior of the testis forming the interfollicular septa (Fig.5).

The spermatogonia appeared with a large nucleus, spherical and central in position with clear nuclear envelope. It appeared euchromatic with dense chromatin, homogeneous in appearance and contained dense nucleoli (sometimes situated peripherally) (Fig.6). The cytoplasm contained mitochondria adjacent to the nuclear membrane on one side of the nucleus, as well as free ribosomes appeared throughout the cytoplasm.

Electron microscope examination of the testes of Anisops sardeus collected from location II (MP) also exhibited many alterations of the general architecture, relative to the testis of location1 (LP).In the epithelial cells, the nucleus appeared with disorganized distribution of heterochromatin clumps and irregular nuclear membrane. In the cytoplasm, mitochondria shows signs of disorganization (Fig.7). Convolution of follicular wall and fibrosis of interfollicular connective tissue were also observed.

Nuclear changes in spermatognia seemed to be more pronounced then cytoplasmic changes (Fig.8). In nuclei, Chromatin condensation and dilation of nuclear envelope were observed. On the other hand cytoplasm contained mitochondria with light matrices. Golgi complex and numerous free ribosomes were also observed.

The electron micrographs of the tests of insects collected from location III (HP) have also some morphological alterations, compared to insects from location 1 (LP).The nucleus of the epithelial cells appeared with aggregated clumps of heterochromatin and irregular nuclear envelope. The cytoplasm appeared with disorganized mitochondria. Convolution of follicular wall were also noticed (Fig.9).

The spermatogonia were morphologically altered. The nucleus appeared with disintegrated nucleolus. In cytoplasm vacuoles predominated. However, some degenerative changes were noted in the mitochondria. These mitochondria display lysis of matrices, disruption of limiting membranes and disintegration of cristae (Fig.9).

\section{Discussion}

In the biomonitoring programs, the biomarkers are used overseas as biomarker of exposure of aquatic organisms to different kind of pollutants (Osman, 2013). Xray microanalysis is useful method to quantify basic elements in biological specimens.

The present study used $\mathrm{x}$-ray microprobe analysis to examine metal accumulation and localization in testes of adult Anisops sardeus collected from three sites at $\mathrm{Al}-$ Mahmoudia canal that differed in their extent to contamination. Various trace elements such as $\mathrm{Cu}, \mathrm{Zn}, \mathrm{A} 1$, $\mathrm{Hg}, \mathrm{Cd}, \mathrm{Fe}, \mathrm{Ca}, \mathrm{Na}, \mathrm{Mg}, \mathrm{P}, \mathrm{S}, \mathrm{Si}$ and $\mathrm{K}$ were detected in the testes of the insects with great frequency of detection occurring in the testes of the insects from the heavily contaminated sites. Similar results were observed by Krantzberg and Stokes (1990), who reported high detection in $\mathrm{Pb}, \mathrm{Fe}, \mathrm{Cd}, \mathrm{Cu}, \mathrm{Ni}, \mathrm{Zn}$ and occasionally $\mathrm{Al}$ in the midgut and papilla of chironomids collected from two sites differ in levels of contamination. Some trace elements originally exited in cytoplasmic matrix or cell organelles of various cells in different organs such as $\mathrm{Zn}, \mathrm{Ca}, \mathrm{S}$ and $\mathrm{Cl}$ (Nagata 2004).

All studies generally showed remarkable variations in pollution by detecting and assessing pollutant in the water. This is the first study that provides the evidence that insects are used in assessing water quality and a significant response of biomarkers can be detected and assessed in field-collected Anisops sardeus from Al-Mahmoudia Canal. In the present study, X-ray spectra of testes of $A$. sardeus from MP and HP sites of Al-Mahmoudia canal demonstrated higher proportions of heavy metals, in particular $\mathrm{Cu}, \mathrm{Zn}$ and $\mathrm{Hg}$ comparable to LP, the reference site. Despite the absence of $\mathrm{Hg}$ in location I (LP) of the canal, it considered the least polluted site. The accumulation and contamination of heavy metals $(\mathrm{Cd}, \mathrm{Cr}$, $\mathrm{Cu}, \mathrm{Ni}$, and $\mathrm{Zn}$ ) in water, were studied by Azam et al., (2015) in few insect species (dragonfly (Crocothemis servilia), an acridid grasshopper (Oxya hyla hyla), and a nymphalid butterfly (Danaus chrysippus)) used as ecological indicators. Study area comes under industrial zone of district Gujrat of Punjab, Pakistan. They found that the total metal concentrations in insects were pointed significantly higher near the industrial sites, whereas lowest value was detected at a site located far from industrial area. They indicated that these insect groups are potential indicators of metal contamination and can be used in biomonitoring.

Agrama and El-Sayed (2013) detected the presence of heavy metals ( $\mathrm{Cu}, \mathrm{Fe}, \mathrm{Mn}, \mathrm{Zn}, \mathrm{Cd})$ in six Western Delta Canals, the water pointed out that the industrial activities, the reuse of agricultural drainage water, as well as nonofficial reuse of drainage affected this water. The water quality parameters data for Western Delta Canals which were based on the Canadian Council of Ministers of the Environment Water Quality Index (CCME-WQI) (CCME, 2001) reported the lowest value at Al-Mahmoudia canal. 


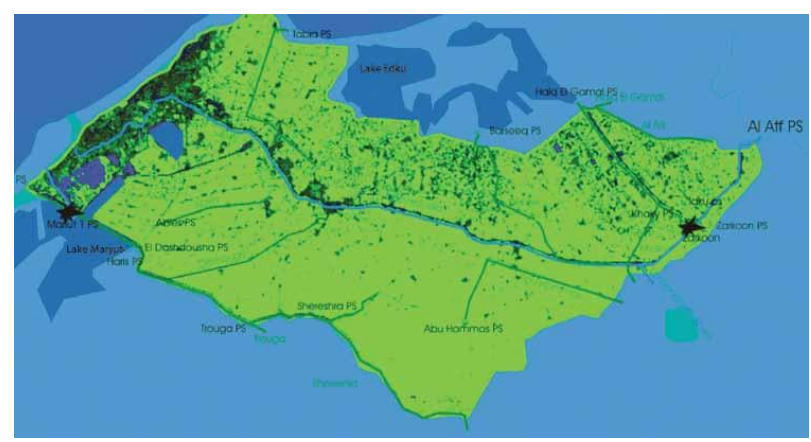

Fig. (1): Map of Al-Mahmoudia canal.

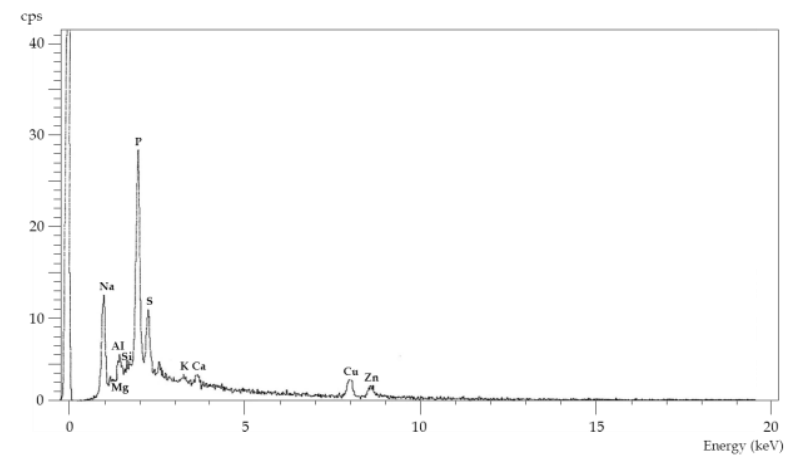

Fig. (2): Energy dispersive X-ray spectra showing the qualitative elemental composition as measured in counts in testes of Anisops sardeus caught from location I (LP) of Al-Mahmoudia canal. Horizontal scale, X-ray energy; vertical scale, X-ray counts.

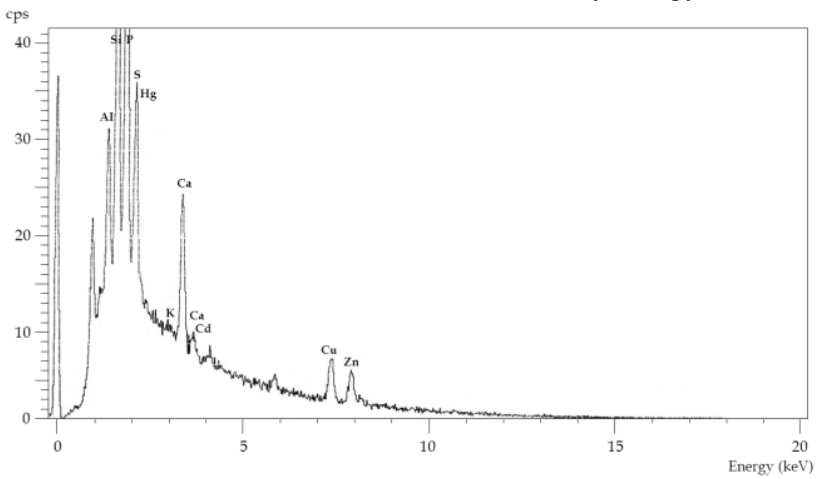

Fig. (3): Energy dispersive X-ray spectra showing the qualitative elemental composition as measured in counts in testes of Anisops sardeus caught from location II (MP) of Al-Mahmoudia canal. Horizontal scale, X-ray energy; vertical scale, $\mathrm{X}$-ray counts.

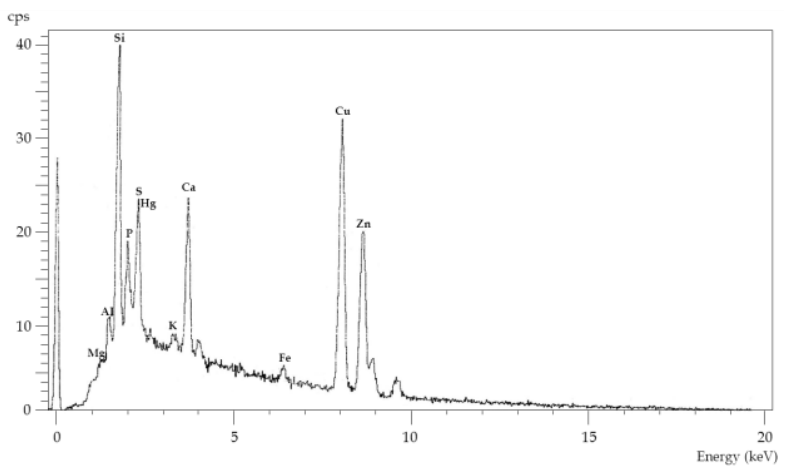

Fig. (4): Energy dispersive X-ray spectra showing the qualitative elemental composition as measured in counts in testes of Anisops sardeus caught from location III (HP) of Al-Mahmoudia canal. Horizontal scale, X-ray energy; vertical scale, X-ray counts. 


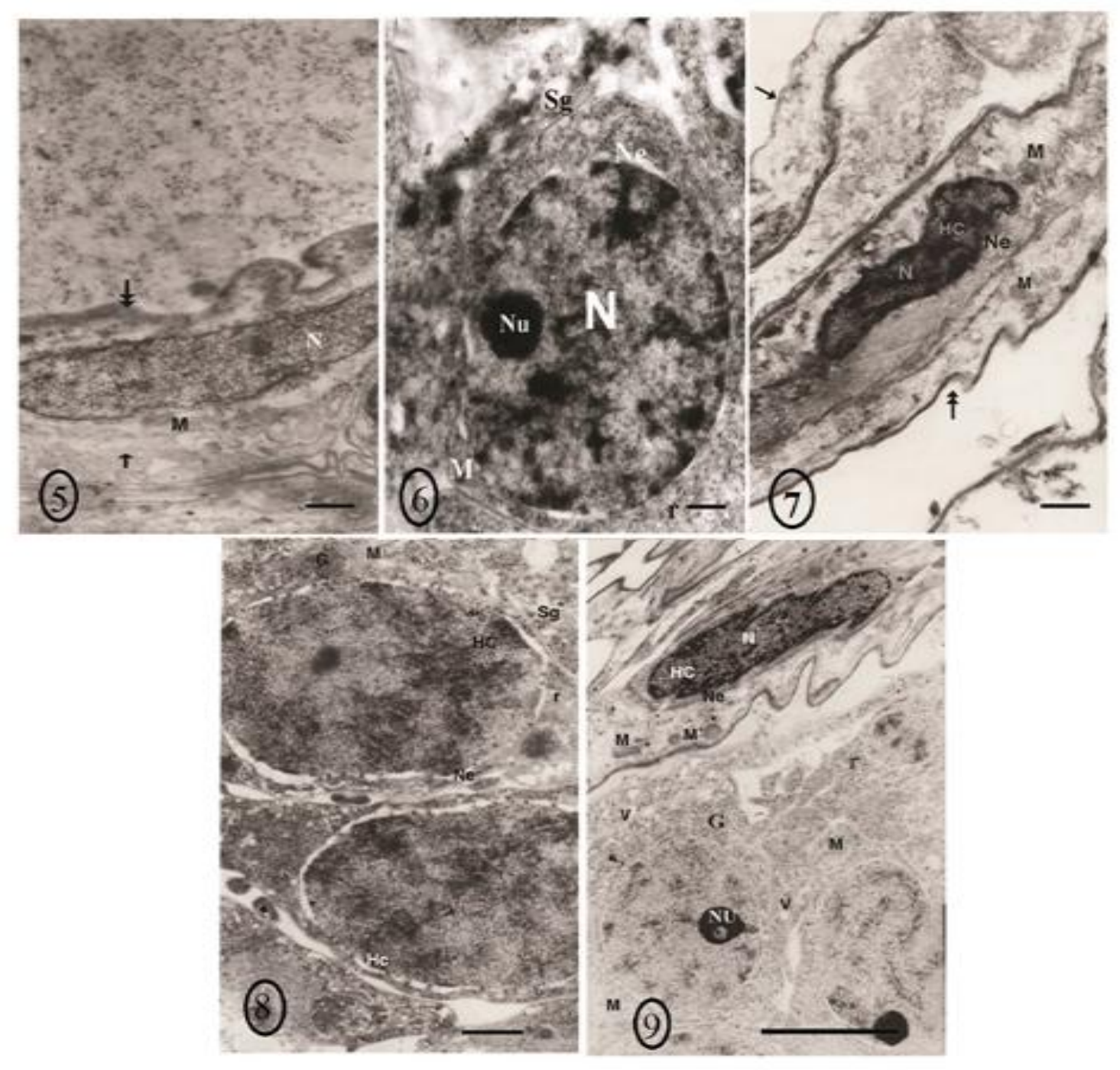

Fig. (5): TEM Showing Flat wireless of epithelial wall (N) Mitochondria (M), interfollicular connective tissue (arrow) and flower wall (double and arrow). Scale bar $=0.25 \mu \mathrm{m}$.

Fig. (6): TEM showing spermatogonia (sg). Note the nucleus (N) with slightly heterogeneous chromatin; Nu: nucleolus; Ne: nuclear envelope; M: mitochondria, $r$ : free ribosomes. Scale bar $=0.25 \mu \mathrm{m}$.

Fig. (7): TEM showing epithelial cell with flat nucleus (N) and irregular nuclear envelope (Ne). Note: aggregated chumps of hetero Chromatin (HC). Note also: disorganization of mitochondria (M). Arrow points at fibrosis of interfollicular connective tissue. Note also, head arrows). Scale bar $=0.25 \mu \mathrm{m}$.

Fig. (8): TEM revealing morphologically altered spermatogoniae (sg) having peripherally aggregated clumps of heterochromatin (HC). Note: dilated nuclear envelope (Ne). M: spherical mitochondria with light matrices. G: Golgi complex, $\mathrm{r}$ : free ribosomes. Scale bar $=0.25 \mu \mathrm{m}$.

Fig. (9): TEM showing epithelial cell with flat nucleus (N) and irregular nuclear envelope (Ne). Note aggregated clumps of hetero-chromatin (HC) and disorganization of Mitochondria (M). Note also morphologically altered spermatogonia $(\mathrm{sg})$, Nucleus $(\mathrm{N})$ with disintegrated nucleolus $(\mathrm{Nu})$; degeneration of mitochondria $(\mathrm{M})$ and vacuolated cytoplasm (v); G: Golgi complex; r: free ribosomes. Scale bar $=0.25 \mu$ 
The deterioration in water quality of Al-Mahmoudia Canal is also due to the pollution of Rosetta Branch which received considerable amounts of untreated industrial effluents (Abd El-Hamid, 1992). Abukila (2012) stated that the majority of water quality problems are occurring in the intake of Al-Mahmoudia canal due to receive low-grade water quality from Rosetta Branch. Abdullah and Hussona (2014) reported that the water quality of Al-Mahmoudia canal exhibited high pollution levels from Zarcon drain and Rosetta branch which create health risks at present and indicates unsafe levels of pollution for direct use in drinking water, irrigation and fisheries.

The present study showed lower percentages of heavy metals $\mathrm{Cu}, \mathrm{Zn}, \mathrm{Al}$ and $\mathrm{Hg}$ in the testis of adult $A$. sardeus sampled from location I (LP). This decrease could be due to the availability of metals for uptake from the medium.

On the other hand, insects from location II (MP) and III (HP) showed high percentage of these heavy metals. These results gain support from the previous study of Sheriff (2007) who reported the toxic effect of heavy metal (Cadmium ) using a species of fresh water aquatic insectnymph of Ephemeroptera Cloeon dipterum (L.) was found to have a significant effect on fine structure of the gills in proportion to the concentration of cadmium used.

Basso et al. (1961), explained the more dangerous effects standing behind the cell death by heavy metal poisoning from pharmological point of view, they reported that within the cells, small amounts of soluble substances containing free sulphydryl groups exerts an inhibitory effect on the activity of sulphydryl enzymes which control the rate of respiration. The removal of free sulphydryl groups by a combination with some heavy metals to an acceleration of respiration and at high concentration the metal become attached to the enzyme molecules themselves and inhibition of oxygen uptake follows. This fact may be stand behind the cell death as an accessory reason which is added to the organelles damage happening when heavy metal poisoning take place.

Heavy metals induced changes in elemental composition in testis of $A$. sardeus in location II and III. The observed disruption of germ cell differentiation in testes of insects sampled from these sites might have caused by alteration in the endocrine system which relies largely on ecdysteroids and on terpenoids (juvenile hormones) which regulate moulting differentiation, metamorphosis and involved in reproductive process such as ovulation and spermoigenesis (Segner et al., 2003). It has been reported by Dedos et al., (2002 a, b) that exposure of fifth instatr larvae of silk worm Bombyx mori (Lepidoptera) to fenoxycarb (1 $\mu \mathrm{g}$ per animal) increased heamolymph juvenile hormone estrase (JHE) and general estrase (GE) activity. It is therefore suggested that if spermatogenesis is disrupted, germ cells will no longer capable of progressing along maturation. Banach et al. (2004), also reported changes in elemental composition of cells in the brain of adult flies after exposure of the larvae to heavy metal $(\mathrm{Cu})$.

Degenerative spermatogenic elements were apparent in testes of insects sampled from location II and III. Such decrease in the quality of gametes may inturn impair the reproductive success of adult organisms. Similar results were obtained by Kherirallah (2006) who worked on the aquatic insect Sphaerodema urinator (Hemiptera) caught from polluted location of Lake Mariut, Alexandria.

The present ultrastructural observation of testis of insects sampled from location I appeared to be wrapped by follicular wall and connective tissue. The epithelial cells appeared with ovoid flat nucleus with homogenous chromatin. The cytoplasm contained mitochondria with variable shapes and sizes. In addition free ribosomes were also present in the cytoplasm. These results are in agreement with the results of Presswalla and Georg (1935), Abdel Gwad (1969), Sabry et al., (1992), Fretias et al., (2003), Kheirallah (2006) and Kheirallah et al.,(2016) who worked on different species of hemiptran and beetles species.

Spermatogonia in the testes of insects sampled from location I appeared with large, central and slightly heterogeneous Chromatin. The cytoplasm contained mitochondria lied close to the nuclear envelope on one side of the nucleus. Free ribosomes were also observed in the cytoplasm. Similar ultrastructural criteria were also observed in the aquatic insect $S$. urinator (Hemiptera) (Kheirallah, 2006).

Ultrastructurally, the testes of insects from location II and III showed many pathological lesions. The epithelial cell displayed irregular nuclear envelope, aggregated clumps of hetero-chromatin, disorganization of mitochondria, fibrosis of interfollicular connective tissue and convolution of follicular wall. These results similarly observed by Kheirallah (2006).

Similar observation was reported by Kumar et al. (2009) who worked on the seminal vesicle of male Loccortrephes ruber (heteroptera) which showed marked changes in insects treated with heavy metal Zinc (25 ppm median lethal concentration). The treated insects showed a highly disintegrated epithelial cells with weakly stained cytoplasm and nuclei with many cytoplasmic vacuoles. Mc Gee et al. (1992) reported that changes in the cell surface morphology including irregulation of membrane contour and focal thickening often occur at an early stage in the course of cell injury, since the cell membrane is the first point of contact with any toxic substance. The structure of the cell membrane often changes as an abnormal cell loses surface receptors and antigenic determinants or gain new ones. The receptors may become abnormally clumped in one part of the cell (Ritchie, 1990).

In spermatogonial cells, nuclear distortion were commonly observed in these germ cells. Similar change resulting from metal toxicity in cell line of the dipteran Aedes albopictus was reported by Braceckman et al., (1999); Braeckman and Raes, (1999); Kheirallah (2006) 
and Kheirallah et al.,(2016). The appearance of distorted nuclei is noteworthy referring to the damaged of RNA metabolism (Bayomi et al., 1979). Appearance of dilated nuclear envelope were also noticed which is in agreement with Braeckman and Raes,(1999), who noticed obvious blebbing in insect's cell line Aedes albopictus exposed to methyl mercury (MeHg). Morphologically altered nuclei were evident in our preparations. These resembled those reported after heavy metal treatment in germ cell lines of the hemiptran insect Triatoma infestans (Mello et al., 1995). In cytoplasm, degeneration of mitochondria was noticed. Pathological reactions of mitochondria to toxins were similarly observed in invertebrate intoxicated cells (Seidman et al., 1986; Hemelraad et al., 1990; Braeckman et al., 1999). Mitochondria alteration reflects deregulation of mitochondrial membrane transport (Braekman et al., 1999). In parallel, Doris et al. (2003), showed that phenol disrupt cytoplasmic membranous structures (mitochondrial cristae, distortion of mitochondrial membranes and nucleus envelope) in sea urchin, Anthocidans crassipina. It is obvious that germ cells were affected by heavy metals, which suggests that heavy metals, disturb cell function at more than one site.

From the results, it was shown that X-ray microanalysis observed by intermediate high voltage scanning electron microscopy was very useful for quantifying some trace elements in biological specimens. This methodology should be utilized in microanalysis of various compounds and elements in various cells and tissues in various organs. In addition, such investigations might provide a more insight into how the toxic metals can alter the natural biology of insects and their ability to produce new offspring. This is an alarm to the governmental authorities indicating that Al-Mahmoudia canal needs more protection.

\section{Acknowledgement}

The author is thankful to Zoology Department, Faculty of science, Alexandria University.

\section{Conflict of interest}

The author has declared no conflict of interest.

\section{Compliance with Ethics Requirements}

All Institutional and National Guidelines for the care and use of animals (insects) were followed.

\section{References}

Abdel-Gawad, A.F. (1969). Anatomy and histology

of the digestive, nervous and reproductive system of Lethocerus niloticum Stal. M.SC. Thesis, Fac. Sci., Alexandria Univ., Egypt.

Abdel-Hamid, M.; Shaaban, D. and Skulberg, O. (1992). Water Quality of the River Nile in Egypt. 1physical and chemical characteristics, Journal of Arch. Hydrobiol., Suppl., 90: 283-310.

Abdullah, M. and Hussona, S. (2014).Water Quality Assessment of Mahmoudia Canal in Northern West of Egypt Ali. J Pollut. Eff. Cont., 2: 121-130.
Abukila, A. F. (2012). Assessment of Natural Self Restoration of the Water of Al-Mahmoudia Canal, Western Part of Nile Delta, Egypt. Irrigat. Drainage Sys. Eng., 1:110.

Agrama, A. and El-Sayed, E. 2013. Assesing and Mapping Water Quality (Case Study: Western DeltaEgypt). International Water Technology Journal, IWTJ, 3: 158-169.

Azam, I.; Afsheen, S.; Zia, A.; Javed, M.; Saeed, R.; Sarwar, M. and Munir, B. (2015). Evaluating Insects as Bioindicators of Heavy Metal Contamination and Accumulation near Industrial Area of Gujrat, Pakistan. Bio. Med. Research International, 11.

Banach, Z.; Borowaska, J.; Pyza E.; Tylko, G. (2004). X-Ray microanalysis method of elemental content evaluation in the brain of Musca domestica exposed to heavy metals. Rad. Phys. Chem., 71: 1001-1002.

Barry, M.J. (1997). Effects of food limitation, notonectid predation, and temperature on the population dynamics of Daphnia carinata. Int. Rev. Hydrobiol., 82: 545-562.

Basso, H.; Rothstein, A. and Clarkson, T. W. (1961). The general pharmacology of the heavy metals. Reviews. 13: $185-224$.

Bayomi, M; Zaafarany, R. and Ramadan, A. (1979). Changes in mice liver after long-term administration of Diazion. El-Azher Med. J., 8: 223-266.

Berchi, G.M. (2011). First record of Anisops sardeus (Hemiptera: Heteroptera: Notonectidae) in Romania. North-Western Journal of Zoology, 7: 339-341.

Braeckman, B.; Brys, K.; Rzeznik, U. and Raes, H. (1999). Cadmium pathology in an insect cell line: ultrastructural and biochemical effects. Tissue and Cell, 31: 45-53.

Braeckman, B. and Raes, H. (1999). The ultrastructural effect and subcellular localization of mercuric chloride and methyl mercuric chloride in insect cells (Aedes albopictus) (6/36). Tissue and Cell, 31: 223232.

Brooks, G.T. (1951). A revision of the genus Anisops (Notonectidae: Hemiptera). Univ. Kansas Sci. Bull., 34: 301-519.

CCME (Canadian Council of Ministers of the Environment) (2001). Canadian water Quality, Guidelines for the protection of aquatic life. CCME water quality index 1.0, Users' manual in Canadian Environment Quality Guidelines.

Cervera, A.; Maym'o, A. C.; Sendra, M.; Mart'ınezPardo, R. and Garcer'a, M. D. (2004). "Cadmium effects on development and reproduction of Oncopeltus fasciatus 
(Heteroptera: Lygaeidae)," Journal of Insect Physiology, 50: 737-749.

Colborn, T.; Vom Saal, F.S. and Soto, A.M. (1993). "Developmental effects of endocrine-disrupting chemicals in wildlife and humans," Env. Health Perspect., 101: 378384.

Creighton, M. and Evans, B.H. (1941). Some effects of X-rays on the germ cells of Chorthippus longicornis (Orthoptera), J. Morphol., 69: 187-205.

Crump, K.L. and Trudeau, V.L. (2009). Mercuryinduced reproductive impairment in fish. Environ. Toxicol. Chem., 28: 895-907.

Dedos, S.G.; Szurdoki, F.; Szekacs, A.; Shiotsuki, T.; Hammock, B.D.; Shimada, J. and Fugo, H. (2002a). Fenoxycarb levels and their effects on general and juvenile hormone esterase activity in the haemolymph of the silkworm, Bombyx mori pest. Biochem. Phys., 73: 174-187.

Dedos, S.G.; Szurdoki, F.; Szekacs, A.; Mizoguchi, A. and Fugo, H. (2002b). Induction of dauer pupae by Fenoxycarb in the silkworm, Bombyx mori. J. Insect. Physiol., 48: 857-865.

Doris, W.; Yurchenko, O. and Reunov, A. (2003). Sublethal effects of phenol on spermatogenesis in sea urchins. Environ. Res., 93: 92-98.

El-Gendy, D. (2013). Impact of environmental stress on some biological strategies of the beetle Tachyderma hispida (Forskal, 1775) inhabiting Mariut region. PhD. Thesis. Faculty of Science, Alexandria University, Egypt.

Freitas, S.; Goncalves, T.; Costa, J. and SantosMallet, J. (2003). Fine structure of the testis of triatomines (Hemiptera, Reduviidae), after the imaginal ecdisis. Acta. Microse., 12:139-140.

Fu, F. and Wang, Q. (2011). Removal of heavy metal ions from wastewaters: A review. J Environ. Manage., 92: 407-418.

Hemelraad, J.; Herwig, H.J.; Van Donselaar, E.G.; Holwerda, D.A. and Zandee, D.I. (1990). Effects of cadmium in freshwater clams. II. Ultrastructural changes in the renal system of Anodonta cygnea. Arch. Environ. Con. Tox., 19: 691-698.

Herranz, L.M.; Teba, F.R.; Martín, R.; Ingelmo, I.; Gómez, V.; Codesal, J.; Pozuelo, J.M.; Oltra, B.; Serna, E. and Santamaría, L. (2010). Quantitative changes in rat seminiferous epithelium after chronic administration of low doses of cadmium and zinc: A Stereological Study. The Open Andrology Journal, 2: 27-36 27.

Hertel-Aas, T.; Deborah, H.; Jaworska, O.A.; Bjerke, H.; Salbua, B. and Brunborgc, G. (2007). Effects of Chronic Gamma Irradiation on Reproduction in the
Earthworm Eisenia fetida (Oligochaeta). Radiat. Res., 168: 515-526.

Kheirallah, D. (2006). Impact of pollution on the water bug, Sphaerodema urinator (Dufour, 1833) inhabiting lakes Mariut and Edku. PhD. Thesis. Faculty of Science, Alexandria University, Egypt.

Krantzberg, G. and Stokes, P. (1990). Metal Concentrations and Tissues Distribution in Larvae of Chironomus with Reference to X-ray Microprobe Analysis. Arch. Environ. Contam. Toxicol., 19: 84-93.

Kumar, T.R.; Emerald, D.M. and Palanivel, A. (2009). Impact of heavy metal zinc on the histological changes in the seminal vesicle of the adult male Laccotrephes ruber (Linn.) (Heteroptera: Nepidae) in relation to reproduction. J. Exp. Zool. 12: 35-37.

Li, G.; Zhao, Z.; Liu, J. and Jiang, G. (2011). Effective heavy metal removal from aqueous systems by thiol functionalized magnetic mesoporous silica. J Hazard Mater, 192: 277-283.

McGee, J.; Isaacson, P.; Wright, N.; Dick, H. and Slack, M. (1992). Oxford text book of Pathology, volume 1, Principles of Pathology. Oxford University Press, Oxford. New York. Tokyo.

Mello, M.; Kubrusly, F.; Randi, M.; Rodrigues, V. and Filho, A. (1995). Effect of heavy metals on chromatin supraorganization, nuclear phenotypes, and survival of Triatoma infestans. Entomol Experiment. Appl., 74: 209218.

Merin Emerald, D. and Rameshkumar, T. (2012). Impact of Heavy Metal Zinc on Histological Changes in the Testis of Adult Male Odontopus varicornis (HeteropteraA: Pyrrhocoridae) in Relation to Reproduction. International Journal of Recent Scientific Research, 3: 791 -794.

Nagata, T. (2004). X-ray microanalysis of biological specimens by high voltage electron microscopy. Prog. Histochem. Cytochem., 39:185-319.

Osman, A.G.M. (2013). Biochemical and Physiological Biomarkers in Aquatic Environmental Research. Proceedings of Basic Appl. Sci., 1857-1879.

Pieterse, G.M. (2004). Histopathological changes in the testis of Oreochromis mossambicus (Cichlidae) as a biomarker of heavy metal pollution. PhD. Thesis. Faculty of Science, Rand Afrikaans University, Johannesburg.

PPIAF (Public-Private Infrastructure Advisory Facility), the World Bank Group, MWRI. (2005). Conceptual Framework and Transaction Model for a Public-Private Partnership in Irrigation in the West Delta, Egypt.

Presswalla, M.J. and George, C.J. (1935). The morphology of Sphaerodema rusticum Fabr. Jour. Univ. of Bombay, 5: 29-57. 
Reynolds, E.S. (1963). Staining of tissue sections for electron microscopy with heavy metals. J. Cell Biol., 17: 203-212.

Ritchie, A.C. (1990). Boyd's textbook of pathology. $9^{\text {th }}$ ed. Volume 1. Lea and Febiger, Philadelphia/London.

Sabry, I.; El-Mofty, M.M. and Abdel-Gawad, A.F. 1992. Enlargement of the interstitial tissue in the testis of the giant water bug Lethocerus niloticum (Heteroptera, Belostomatidae) in the breeding season. J. Egypt. Ger. Soc. Zool., 9: 31-41.

Seidman, L.A.; Bergtrom, G. and Remsen, C.C. (1986). Structure of the larval midgut of the fly Chironomus thummi and its relationship to sites of cadmium sequestration. Tissue and Cell, 18: 407-418.

Senger, H.; Caroll, K.; Fenske, M.; Janssen, C.R.; Maack, G.; Pascoe, D.; Schafers, C.; Vandenbergh, G.F.; Watts, M. and Wenzel, A. (2003). Identification of endocrine-disrupting effects in aquatic vertebrates and in invertebrates: report form the European IDEA Project. Ecotoxicol. Environ. Saf., 54: 302-314.

Sharp, R.M. and Skakkeboek, N.E. (1993). "Are estrogens involved in falling sperm counts and disorders of the male reproductive tract?," Lancet, 341: 1392-1395.

Sheriff, A.H. (2007). Cellular Ultra Structural Damage by Heavy Metal Cadmium Toxicity AJPS, 4: 1-17.

Sildanchandra, W. and M. Crane, M. (2000). "Influence of sexual dimorphism in Chironomus riparius Meigen on toxic effects of cadmium," Environmental Toxicology and Chemistry, 19: 2309-2313.

Sprague, J.B. (1971). Measurement of pollutant toxicity to fish: III. Sublethal effects and "safe" concentration. Water Res., 5: 245-266.

Suzuki, J. and Egami, N. (1984). Radiation-induced damage and recovery from it in germ cells in the earthworm, Eisenia foetida. J. Faculty Sci. Univ. Tokyo, Sec. IV Zool., 15: 329-342.
Tempelman, D. and von Haaren, T. (2009). Water en Oppervlaktewantsen van Nederland. Jeugd bond suitgeverij, Utrecht, $116 \mathrm{pp}$.

Toppari, J.; Larsen, J.C.; Christiansen, P.; Giwercman, A.; Grandjean, P.; Guillette, L.J.; Jegou, B.; Jensen, T.K.; Jouannet, P.; Keiding, N.; Leffers, H.; McLachlan, J.A.; Mever, O.; Muller, J.; Rajpert-De Meyts; E., Scheike, T.; Sharpe, R.; Sumpter, J.and Skakkeboek, N.E. (1995). "Male reproductive health and environmental chemicals with estrogenic effects," Milijoprojekt 290, 166 pp., Ministry of the Environment and Energy, Danish Environmental Protection Agency, Copenhagen.

Welshons, W.J. and Russel, W.L. (1957). The effect of X-rays on the Drosophila testis and a method for obtaining spermatogonial mutation rates, Proc. Natl. Acad. Sci. U.S.A., 43: 608- 613. 